\title{
Prevalence of Metabolic Syndrome and Associated Risk Factors in Medical Students of Universidad Central Del Ecuador
}

\author{
Ruano NC ${ }^{*}$, Melo Pérez J1, Mogrovejo FL ${ }^{1}$, De Paula Morales K ${ }^{1,2}$, Espinoza Romero CV CV $^{1,2}$ \\ ${ }^{1}$ Unit of Metabolic and Infectious Diseases, Faculty of Medical Sciences, Universidad Central Del Ecuador, Quito, Ecuador \\ ${ }^{2}$ Ninth semester medical students, Universidad Central Del Ecuador, Quito, Ecuador
}

Received: April 07, 2015; Accepted: June 11, 2015; Published: August 11, 2015

*Corresponding author: César Ruano Nieto, Faculty of Medical Sciences, Universidad Central Del Ecuador, Iquique N14-121 and Sodiro Street, Email: ciruano@uce.edu.ec/cesarruano@terra.com

\begin{abstract}
Introduction: There is evidence that obesity increases cardiovascular risk and Metabolic Syndrome (MS) in children, adolescents and adults. Inflammation plays an important role in the development of these diseases. Today, obesity in children and adolescents is a serious public health problem and appears to be the most important cause of insulin resistance, which makes them a risk group for developing metabolic syndrome.
\end{abstract}

Objective: To determine the prevalence of metabolic syndrome and associated predisposition factors among students of the first three semesters from the school of Medicine, Faculty of Medical Sciences of the Universidad Central Del Ecuador.

Methods: We included medical students from the first three semesters of the Universidad Central Del Ecuador. The students weight, height, blood pressure, waist circumference were measure and BMI was calculated. Furthermore, total cholesterol levels in serum, HDL cholesterol, LDL cholesterol, triglycerides, glucose, insulin, hsCRP, IL-6 were determined and the HOMA-IR was calculated.

Results: 883 medical students were studied, with a mean age of $19.3 \pm 1.4$ where $67 \%$ were female. The prevalence of MS was $8.2 \%$ $(\mathrm{n}=73), 68 \%$ were women and $32 \%$ men. $29.3 \%$ of men presented pre obesity or obesity compared with $23.3 \%$ of women $(p>0.05)$. It was found that waist circumference was preferentially altered in women compared to men $(52.3 \%$ vs $26.2 \%)(p<0.05) .39 .7 \%$ of women had HDL levels below the normal values versus $18.2 \%$ in males $(p<0.05)$. The values of total cholesterol, LDL cholesterol and glucose were within normal parameters. The blood pressure levels were above the normal range in men more than in women $(24.4 \%$ vs $9.8 \%)(p<0.05)$. $19.4 \%$ of the total population presented hsCRP values between $1-3$ $\mathrm{mg} / \mathrm{l}$ and $7.4 \%$ between $3-9 \mathrm{mg} / \mathrm{l}$. The $7.48 \%$ had altered levels of IL-6 $(>3.1 \mathrm{pg} / \mathrm{ml})$ and was found a slight increase in students with overweight, obesity and MS. Insulin resistance was found in both groups, the one with normal BMI as well as in the overweight and obesity group, $15.3 \%$ and $14.4 \%$ respectively.

Conclusion: The prevalence of metabolic syndrome was $8.2 \%$ and only $34 \%$ of the population presented no risk factors for MS. 1 out of 4 students presented some degree of overweight or obesity. A directly proportional relationship between the presence of risk factors and increased blood pressure was evident. Given the large number of individuals who have at least one risk factor, it is crucial to promote a healthy lifestyle that includes non-pharmacological interventions such as diet and exercise.

Keywords: Metabolic syndrome; Obesity; Dyslipidemia

\section{Introduction}

Nowadays, adolescent obesity is a serious public health problem. In developed countries, there are about 110 million young people suffering from overweight or obesity [1].

It is known that obesity increases cardiovascular risk and metabolic syndrome in children [2], adolescents and adults [3]. It is also known that inflammation plays an important role in scientific and technical development of these diseases [4]. Changes in lifestyle caused by the evolution of our era have been listed as one of the determining factors that trigger this condition [5]. In children and adolescents, obesity seems to be the most important cause of insulin resistance, which makes them a risk group for developing Metabolic Syndrome (MS) [6]. Some authors attribute these percentages of overweight and obesity to the lack of physical activity that is becoming more common in younger children. Physical activity was inversely associated with various metabolic indicators such as lipid profile, insulin resistance and High Blood Pressures (HBP), components of MS. However, physical activity must meet certain conditions (type, intensity, frequency and duration), in order to be efficient [7]. Sedentary people were found to have abnormalities in their lipid profile, including high triglycerides, low HDL cholesterol, elevated nonHDL cholesterol and Apo B, all those associated with an increased cardiovascular risk [8].

Until recently, adipose tissue was considered only as an energy storage site, but it is now known to be an active metabolic tissue that releases a number of bioactive mediators called adipokines. Some of these mediators (TNF-alpha, IL-6, IL-1) induce a systemic low-grade inflammation in people with excessive corporal fat [9].

Recent studies suggest a possible link between the development of cardiovascular disturbances and a state of chronic low-grade inflammation in these patients [4]. This inflammation is mediated by alterations in adipose tissue secretions, including: cytokines such as ceruloplasmin, leptin, adiponectin and Interleukin 6 (IL-6) [10-12]. These substances together with increased levels of blood lipids are risk factors for the early development of cardiovascular disease [13], which means that 
serum determination of these mediators in adolescents is an effective tool to predict and prevent cardiovascular diseases [1416].

Several studies have shown the sensitivity of IL-6 in relation to increases in body weight, for that reason it is considered an excellent marker of metabolic syndrome [17].

Moreover, features exhibited by IL- 6 suggest that it functions as a potent inducer of the acute phase in the inflammatory process in young obese people [17].

C-reactive protein (CRP) is an acute phase protein produced by the liver in response to factors that are released by adipocytes. This protein increases in the same pattern as IL- 6 in acute and chronic inflammatory diseases and is an independent predictor of myocardial infarction, arterial disease, and sudden cardiac death, even in healthy people [18]. CRP levels reflect inflammation and this relates to the lifestyle of a person, including dietary and physical activity. It has also been associated with insulin resistance and atherosclerosis in adults [19].

CRP is considered a strong indicator of future heart disease [20], elevated serum concentrations found in obese adolescents show the higher risk of cardiovascular events that these young individuals have [21]. Several studies have also shown that, along with the elevation of CRP and cytokines in these patients, resistance to the action of insulin is also increased [16,22].

Combined analysis, including anthropometry and computerized tomography studies have shown a strong association between waist circumference (WC)and abdominal fat, so it has given the WC a discriminatory capacity, higher than the Body Mass Index (BMI) and waist-hip ratio, considering it a risk marker of chronic diseases such as hypertension, diabetes mellitus type 2 and cardiovascular disease [23].

In Ecuador, the follow-up given to the diagnosis of MS to predict the risk of cerebrovascular disease and diabetes mellitus is limited. Although there is significant, but sporadic evidence to justify the study of MS, there are few publications about it. Perhaps the most significant is that reported in a study conducted on a sample of male population, between the ages of 30 and 60 , from the Ecuadorian highlands, in which the MS prevalence was 13.4\% according to ATP III criteria and 33.1\% according to IDF [24]. There are not studies on MS and its risk factors in young people. Data published in the National Health and Nutrition Examination Survey (ENSANUT-ECU) 2011-2013, indicate that the prevalence of overweight and obesity in Ecuadorian adolescents between the age 12 to 19 is $26 \%$ while in individuals over 19 years old rises to $62.8 \%$. It was higher in women (65.5\%) than men $(60 \%)$ [25]. Other authors found an overweight and obesity prevalence of $13.7 \%$ in women and $7.5 \%$ in men [26]. We work with medical students between 17 and 25 years old giving us a prevalence of $7.58 \%$ metabolic syndrome, $22.24 \%$ pre obesity and $3.14 \%$ obesity [27].

Nutritional recommendations for the MS aim to improve insulin sensitivity and prevent or treat metabolic disorders. Although some of the nutrients in the diet can influence insulin sensitivity, more benefits are obtained with weight loss [28]. Several studies recommend reducing consumption of saturated fatty acids and trans fatty acids, and increase consumption of Mono Unsaturated Fatty Acids (MUFA) and Poly Unsaturated Fatty Acids (PUFA) [29]. The MUFA and PUFA consumption helps control blood pressure (BP), clotting, endothelial function and insulin resistance, therefore, having beneficial effects in preventing and treating MS [30].

Students attending university have a tendency to adopt unhealthy eating habits, sedentary habits and a lifestyle characterized by stress and long schedules that results in the consumption of less nutritious food, irregular meal times and lack of exercise and obesity [31,32].

This investigation presents the results of the study on the prevalence of metabolic syndrome and associated risk factors in medical students of the first three semesters of faculty of Medical Sciences of the Universidad Central Del Ecuador (UCE) and the relation between insulin resistance and metabolic syndrome components.

\section{Materials and Methods}

This is an epidemiological, analytical, cross-sectional study in which the risk factors associated and the prevalence of metabolic syndrome was determined.

It included all students enrolled in first, second and third semester of the School of Medicine, Faculty of Medical Sciences of the UCE, period October 2014 - March 2015, that decided to participate voluntarily before signing an informed consent (Approved by the Ethics Committee of the Faculty of Medical Sciences of the UCE). 883 students were incorporated. All tests were performed in a special office prepared for that purpose in the Faculty of Medical Sciences of UCE. All students answered a survey in which information on personal data, personal medical history, family medical history, eating habits, alcohol consumption, smoking habits, and exercise habits were collected.

Students were weighed and measured in light clothing and with no shoes using a SECA weighting scale (new, factory calibrated), BMI was determined. The abdominal and hip circumferences were measured with a tape measure, according to international standards. The BP was measured using a Riestermercury sphygmomanometer (new, factory calibrated) by a single researcher previously trained to avoid measurement bias. BP was measured after at least a 5-minute break with the student in sitting position, placing the sleeve on the left arm. If there was any concern with the BP measurement the student's $\mathrm{BP}$ was retested for a second time after a 10 minutes rest. The value used was the average between the two measures.

All students were scheduled for specific times in the morning after a 12-hour fasting, we took a sample of venous blood (from the elbow crease), from which the plasma was separated. The data collected was: Blood chemistry which included urea, glucose, creatinine, uric acid, lipid profile: Total cholesterol (TC), triglycerides, HDL, using a Roche Modular analyzer with P- 800 enzymatic colorimetric method, LDL was calculated using the 
equation Friedewall.They were taken as cutoff points for each variable established by WHO and IDF $[5,33]$.

A data sample of serum was stored at -70 degrees Celsius for further processing to determine high-sensitivity CRP, IL-6 and insulin. CRP (Latex) HS (Tina quant ${ }^{\circledR}$ C-reactive protein) was quantified in a Modular analyzer Evo P800 using the immunoturbidimetric method: latex particles Acs monoclonal mouse anti-CRP with a detection limit of quantification of $0.1 \mathrm{mg}$ / L; Interleukin 6 (IL-6) was determined using the Immulite 2000 Immunometric sequential chemiluminescent solid phase method with a quantification limit of $2 \mathrm{pg} / \mathrm{ml}$ and insulin was measured using an Evo Modular E170 analyzer, using the method ECLIA / Anti-Insulin antibody (Biotin) Acs Acs anti-insulin-Ru, with a limit of quantification of $0.20 \mathrm{US} / \mathrm{ml}$.

HOMA-IR index, described by Matthews et al. [34] and validated by several authors for epidemiological studies, that is the product of fasting insulin (microU / ml) and the glucose in blood was used for the assessment of insulin resistance Fasting (mmol / L) divided by 22,5.35 As cutoff HOMA-RI $\geq 2,5$ was used $[35,36]$.

For determination of IL-6 and insulin, we included all students who were overweight or obese and as a control group an equal number of students with normal weight based on BMI were included randomly.

Students who do not perform physical activity at least 3 times (days) a week were classified as sedentary people.

A database in Microsoft Excel 2010 and statistical analysis was done using SPSS 21 . The results are presented in the tables and graphs below. Statistical tests used were: measures of central tendency, confidence intervals at 95\%, chi x2, T test and Mann Whitney, ANOVA, Pearson correlation and association measures Odds Ratio, with its values of $\mathrm{p}$, Cut off points court were taken from WHO, IDF and laboratory reference values to perform the sample analysis.

\section{Results}

883 college students with a range of 17-25 years were included in the study, the average age was $19.3 \pm 1.4$, and $67 \%$ of the participants were female.

Table 1 shows the average anthropometric and biochemical variables presented by gender, by making a comparative analysis; it was found that both men and women have a similar BMI. Waist circumference average is increased in women; men have a higher Systolic Blood Pressure (SBP) and Diastolic Blood Pressure (DBP), women showed higher total cholesterol, while men presented higher triglyceride values. The mean difference between men and women was statistically significant $(p<0.05)$ in waist circumference, SBP, DBP, total cholesterol, HDL cholesterol, triglycerides and glycemia.

Table 2 shows the prevalence of risk factors for MS according to gender. In the general population, it was found that $22 \%$ were overweight and $3 \%$ obese. In women, $20.9 \%$ were overweight and $2.3 \%$ obese, while men had $24.7 \%$ and $4.6 \%$ of overweight
Table 1: Average anthropometric and biochemical variables according to the gender

\begin{tabular}{|l|l|l|l|}
\hline Variable & Female & Male & p \\
\hline BMI & $23.15 \pm 3.06$ & $23.57 \pm 3.38$ & 0.06 \\
\hline Waist diameter $(\mathrm{cm})$ & $80.5 \pm 7.6$ & $84.3 \pm 9.1$ & 0.0001 \\
\hline SBP $(\mathrm{mm} / \mathrm{hg})$ & $114 \pm 10.0$ & $119 \pm 11.8$ & 0.0001 \\
\hline DBP $(\mathrm{mm} / \mathrm{hg})$ & $71.9 \pm 8.0$ & $75.5 \pm 8.8$ & 0.0001 \\
\hline Total cholesterol (mg/dl) & $160.2 \pm 27.7$ & $155 \pm 29.4$ & 0.01 \\
\hline c HDL (mg/dl) & $53.7 \pm 11.9$ & $48.0 \pm 10.0$ & 0.0001 \\
\hline c LDL (mg/dl) & $87.6 \pm 23.6$ & $86.6 \pm 26.8$ & 0.55 \\
\hline Triglycerides (mg/dl) & $94.9 \pm 45.6$ & $103.0 \pm 51.1$ & 0.01 \\
\hline Glycemia (mg/dl) & $80.8 \pm 6.5$ & $81.9 \pm 6.7$ & 0.01 \\
\hline
\end{tabular}

Table 2: Prevalence of risk factors evaluated in relation to gender.

\begin{tabular}{|c|c|c|c|}
\hline & $\begin{array}{l}\% \text { Female }(n= \\
559)\end{array}$ & $\%$ Male $(n=324)$ & $\mathbf{p}$ \\
\hline Overweight / Obesity & 23.3 & 29.3 & \multirow{3}{*}{0.46} \\
\hline $\begin{array}{l}\text { Overweight (25 - } 29.9 \\
\mathrm{~kg} / \mathrm{m} 2)\end{array}$ & 20.9 & 24.7 & \\
\hline Obesity (>30 kg/m2) & 2.3 & 4.6 & \\
\hline Waist circumference & \multirow[b]{2}{*}{52.3} & \multirow[b]{2}{*}{26.2} & \multirow[b]{2}{*}{0.001} \\
\hline $\begin{array}{l}\text { (men >90/women } \\
>80)\end{array}$ & & & \\
\hline $\begin{array}{l}\text { Total cholesterol } \\
(>200 \mathrm{mg} / \mathrm{dl})\end{array}$ & 7.9 & 5.2 & \multirow{3}{*}{0.12} \\
\hline $\begin{array}{l}\text { High Limit (200 - } 239 \\
\mathrm{mg} / \mathrm{dl})\end{array}$ & 7.2 & 4 & \\
\hline Elevated $(>240 \mathrm{mg} / \mathrm{dl})$ & 0.7 & 1.2 & \\
\hline $\begin{array}{l}\text { cHDL }<40 \mathrm{mg} / \mathrm{dl} \text { men, } \\
<50 \mathrm{mg} / \mathrm{dl} \text { women }\end{array}$ & 39.7 & 18.2 & 0.001 \\
\hline $\mathrm{cLDL}>100 \mathrm{mg} / \mathrm{dl}$ & 24.9 & 26.9 & \multirow{4}{*}{0.71} \\
\hline $\begin{array}{l}\text { Superior (100 - } 129 \\
\mathrm{mg} / \mathrm{dl})\end{array}$ & 19.9 & 22 & \\
\hline $\begin{array}{l}\text { High Limit (130 - } 159 \\
\mathrm{mg} / \mathrm{dl})\end{array}$ & 4.3 & 3.7 & \\
\hline High (>160 mg/dl) & 0.7 & 1.2 & \\
\hline $\begin{array}{l}\text { Triglycerides }>150 \\
\mathrm{mg} / \mathrm{dl}\end{array}$ & 10.6 & 12.3 & \multirow{3}{*}{0.63} \\
\hline $\begin{array}{l}\text { High Limit (150 - } 199 \\
\mathrm{mg} / \mathrm{dl})\end{array}$ & 6.6 & 8.3 & \\
\hline $\begin{array}{l}\text { High (200 - } 400 \text { mg/ } \\
\text { dl) }\end{array}$ & 3.9 & 4 & \\
\hline $\begin{array}{l}\text { Blood pressure } \\
(>130 / 85 \mathrm{mg} / \mathrm{dl})\end{array}$ & 9.8 & 24.4 & 0.001 \\
\hline Glycemia (>90 mg/dl) & 6.4 & 11.1 & 0.01 \\
\hline Smoking & 7.3 & 19.8 & 0.001 \\
\hline Sedentary lifestyle & 92.5 & 75 & 0.001 \\
\hline
\end{tabular}

and obesity respectively. The waist circumference was altered (women $>80 /$ men $>90$ ) in $52.3 \%$ of women and $26.2 \%$ of men (p0.001). HDL cholesterol was altered in $39.7 \%$ of women versus $18.2 \%$ of men ( $\mathrm{p}$ 0.001). BP levels were above the normal range in men more than in women $(24.4 \%$ vs $9.8 \%$, p 0.001). Total cholesterol values, LDL, triglycerides and glucose, have shown no statistically significant differences between genders. Tabaco consumption is higher in men than in women $(19.8 \%$ vs $7.3 \%$, p0.001). In relation to the sedentary lifestyle, the number of 
women who are not physically active is greater than that of men (92.5\% vs $75 \%$, p0.001).

The prevalence of MS was $8.2 \%(n=73)$, where $68 \%$ were women and $32 \%$ men. The $16.08 \%$ of students had at least two risk factors for the development of MS, only $34.65 \%$ of the study population did not present any risk factors (Graph 1).

The prevalence of MS according to BMI and gender (Graph 2) was also calculated, in which $4.40 \%$ of women and $1.70 \%$ of normal-weight men had MS, overweight prevalence increased to $23.10 \%$ in females and $15.00 \%$ for men and when present obesity rises to $30.80 \%$ and $46.70 \%$ in males and females respectively.

The risk of developing MS in overweight women was 6.75 (3.66 -12.45) times that of women with normal weight ( $p 0.001)$ while in the overweight or obese men the risk was 14.06 (4.63 42.63) times more than men with normal BMI (p0.001).

In the general population categorized by BMI and presence of MS it was found statistically significant differences in the averages of all the variables studied in Table 3. In relation to fasting glucose, this parameter was plotted in a graph versus BMI (Graph 3). It is observed a slight trend for the glucose to increase when the BMI does.

Regarding the inflammatory markers, $19.4 \%$ of the general population presented CRP values between $1-3 \mathrm{mg} / \mathrm{l}, 7.4 \%$ of 3-9

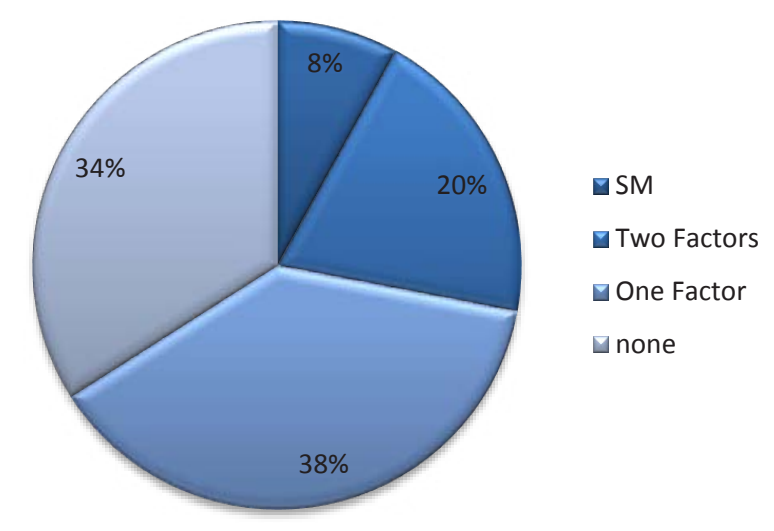

Graph 1: Risk factors for MS (n=883).

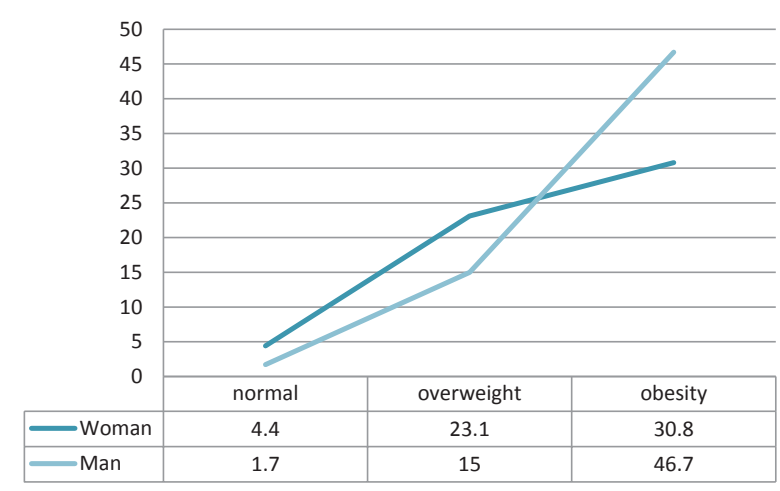

Graph 2: Prevalence of MS according to BMI. $\mathrm{mg} / \mathrm{l}$ and 7.48\% had altered levels of IL6 (> $3.1 \mathrm{pg} / \mathrm{ml}$ ). The average CRP was lower in students with a BMI $>25 \mathrm{~kg} / \mathrm{m} 2$ in relation to the group of $<25 \mathrm{~kg} / \mathrm{m} 2$, so do MS carriers where the average is lower compared to those who do not have MS.

The average values found in IL6 as BMI $<25 \mathrm{~kg} / \mathrm{m} 2$ and $>25$ $\mathrm{kg} / \mathrm{m} 2$ show a slight increase in the values of IL6 in the group of overweight and obesity (p0.0001) and in the group with MS (p0.0001) (Table 4).

It was also found that $70.3 \%$ of the students who exercise three or more days a week and more than thirty minutes (nonsedentary), have a normal BP contrary to those who do not perform any activity (sedentary) where the percentage normal BP was of $52.27 \%$, this difference is statistically significant. In addition, the last group was found to have an increased risk for developing a BP altered OR 1.96 (1.30 - 2.97) (p0.001) (Table 5).

Regarding the BP, statistically significant differences were found in all variables when BP was high (> 135/85 mmHg) (Table 6).

Insulin resistance (HOMA-IR index) was plotted in a graph versus BMI (Graph 4). The graph does not show a clear relationship between insulin resistance and BMI. When the parameters were stratified by sex, a significant relationship was not found (Graph 5).

\section{Discussion}

In this study, $8.2 \%$ were diagnosed with MS (IDF), the prevalence in women was higher $(68 \%)$. Similar studies conducted in other countries such as Colombia, Chile and Venezuela showed overall prevalence of 2\% (IDF), [37] 1.8\% (IDF) [38] and 3.3\% (NCP ATPIII) [39], respectively. Moreover a Mexican study found a prevalence of $7.8 \%$ in a similar population (NCP ATPIII) [40]. An important feature to point out it that the $16.08 \%$ of students had at least two risk factors for the development of MS and about $50 \%$ at least one, same as described in a study in similar populations in Mexico [41]. Only 34.65\% of the study population did not present any risk factor.

In this study, $29.3 \%$ of men were overweight or obese compared with $23.3 \%$ in women, which is consistent with studies in Mexico [42,43], Venezuela [39] and Chile [38] these factors were higher in men.Data from ENSANUT-ECU conducted by the Ministry of Public Health of Ecuador reports that the prevalence of pre-obesity and obesity in adolescents between 12 to 19 years old is $26 \%$ and population of $19-60$ years old $62.8 \%$ [25] In relationship to $\mathrm{WC}$, women had a major alteration which is consistent with data from several studies in Latin America $[37,38,40,43]$, but not with those found by Trujillo-Hernandez et al. who reported that the WC was preferentially altered in men [42] this agrees with the growing trend of the worldwide obesity in children and adolescents and our study group is not an exception.

Total cholesterol, LDL and glucose values are not altered in most of the sample, unlike other studies [37,39] Surprisingly, HDL alterations found in this study occurred predominantly in women 
Table 3: Average anthropometric and biochemical variables as BMI and presence of MS.

\begin{tabular}{|l|l|l|l|l|l|l|l|}
\hline \multicolumn{2}{|l}{ BMI } & \multicolumn{3}{l}{ MS } & \multicolumn{2}{l|}{} \\
\hline Variable & Normal & Overweight & Obesity & p & YES & NO & P \\
\hline BMI & $21.85 \pm 1.04$ & $26.82 \pm 1.24$ & $32.68 \pm 2.27$ & 0.0001 & $26.72 \pm 3.39$ & $23.00 \pm 2.98$ & 0.0001 \\
\hline $\begin{array}{l}\text { Waist circumference } \\
\text { (cm) }\end{array}$ & $78.8 \pm 6.3$ & $89.5 \pm 5.5$ & $99.7 \pm 9.8$ & 0.0001 & $91.0 \pm 7.7$ & $81.0 \pm 7.9$ & 0.0001 \\
\hline SBP (mm/hg) & $114.7 \pm 10.8$ & $119.4 \pm 10.4$ & $126.1 \pm 11.9$ & 0.0001 & $123.1 \pm 11.3$ & $115.5 \pm 10.8$ & 0.0001 \\
\hline DBP (mm/hg) & $72.3 \pm 8.4$ & $75.2 \pm 8.0$ & $80.8 \pm 9.5$ & 0.0001 & $78.4 \pm 9.4$ & $72.8 \pm 8.3$ & 0.0001 \\
\hline $\begin{array}{l}\text { Total cholesterol } \\
\text { (mg/dl) }\end{array}$ & $156.7 \pm 27.2$ & $163.3 \pm 31.8$ & $162.7 \pm 26.5$ & 0.011 & $172.5 \pm 25.2$ & $157.1 \pm 28.4$ & 0.0001 \\
\hline cHDL (mg/dl) & $52.8 \pm 11.7$ & $49.1 \pm 10.2$ & $41.2 \pm 9.4$ & 0.0001 & $41.4 \pm 9.1$ & $52.6 \pm 11.3$ & 0.0001 \\
\hline cLDL (mg/dl) & $85.2 \pm 23.2$ & $92.8 \pm 28.6$ & $94.8 \pm 25.3$ & 0.0001 & $96.6 \pm 24.5$ & $86.4 \pm 24.7$ & 0.001 \\
\hline $\begin{array}{l}\text { Triglycerides (mg/ } \\
\text { dl) }\end{array}$ & $92.6 \pm 43.1$ & $109.3 \pm 51.2$ & $141.3 \pm 83.1$ & 0.0001 & $175.9 \pm 76.4$ & $90.8 \pm 37.1$ & 0.0001 \\
\hline Glycemia (mg/dl) & $80.8 \pm 6.6$ & $82.3 \pm 6.5$ & $83.4 \pm 7.6$ & 0.004 & $83.3 \pm 6.8$ & $81.0 \pm 6.6$ & 0.05 \\
\hline
\end{tabular}

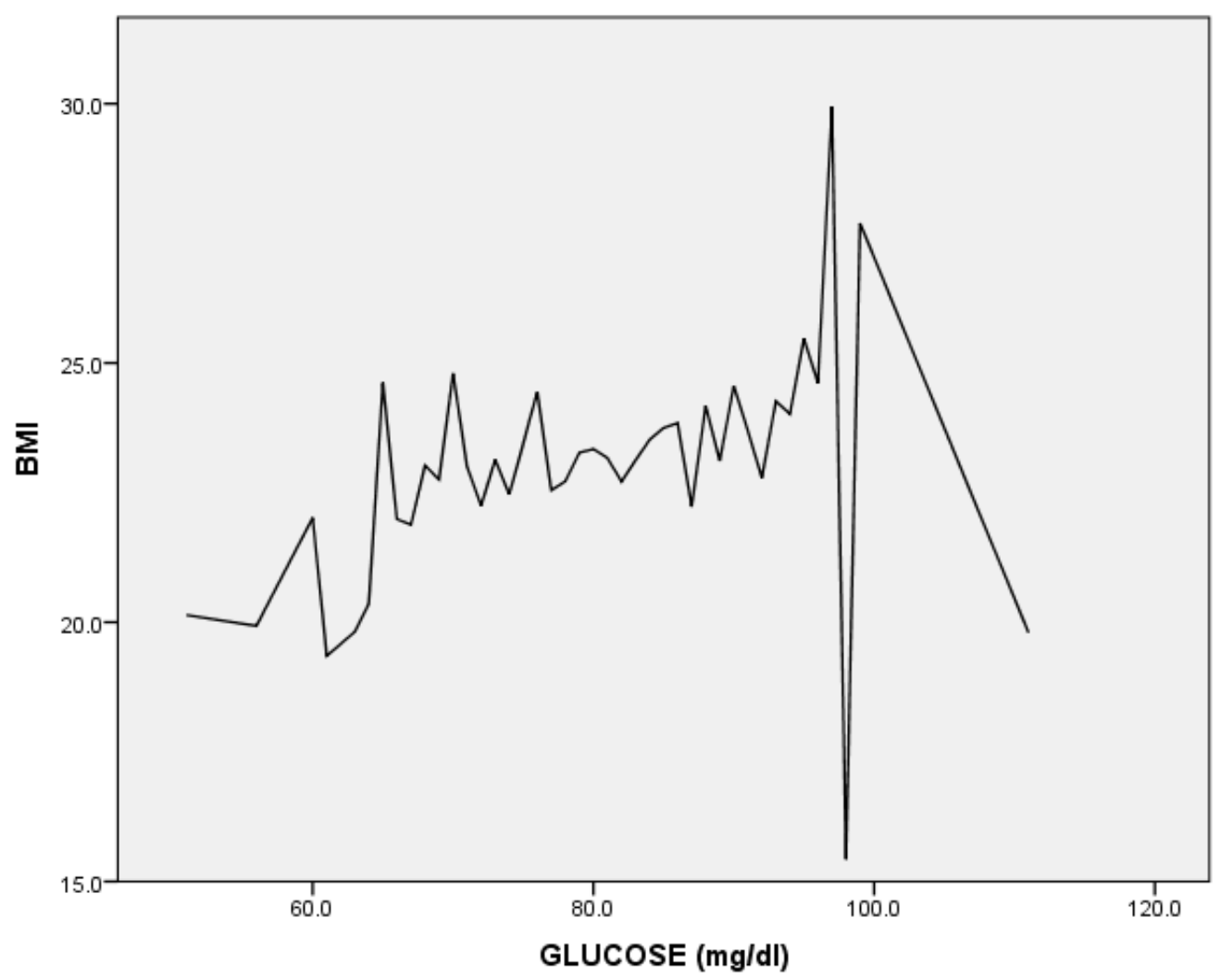

Graph 3: Fasting Glucose vs. BMI.

Table 4: Average of inflammatory markers in relation to the presence of MS, WC and BMI.

\begin{tabular}{|l|l|l|l|l|l|}
\hline \multirow{2}{*}{ Waist circumference } & Hs CRP & p & IL6 & p \\
\hline \multirow{2}{*}{ Population } & Abnormal & $0.431 \pm 0.533$ & $p>0.05$ & $2.609 \pm 1.14$ & $p>0.05$ \\
\cline { 2 - 6 } & Normal & $1.01 \pm 0.955$ & & $2.522 \pm 1.818$ & $p>0.05$ \\
\hline \multirow{2}{*}{ BMI } & Healthy & $1.018 \pm 0.959$ & & \\
& MS & $0.434 \pm 0.505$ & $p<0.05$ & $2.513 \pm 1.823$ & \\
\hline
\end{tabular}

Citation: Ruano Nieto CI, Melo Pérez JD, Mogrovejo Freire LE, De Paula Morales KR, Espinoza Romero CV (2015) Prevalence of Metabolic Syndrome and Associated Risk Factors in Medical Students of Universidad Central Del Ecuador. J Endocrinol Diab 2(3): 10. DOI: http://dx.doi.org/10.15226/2374-6890/2/3/00128 


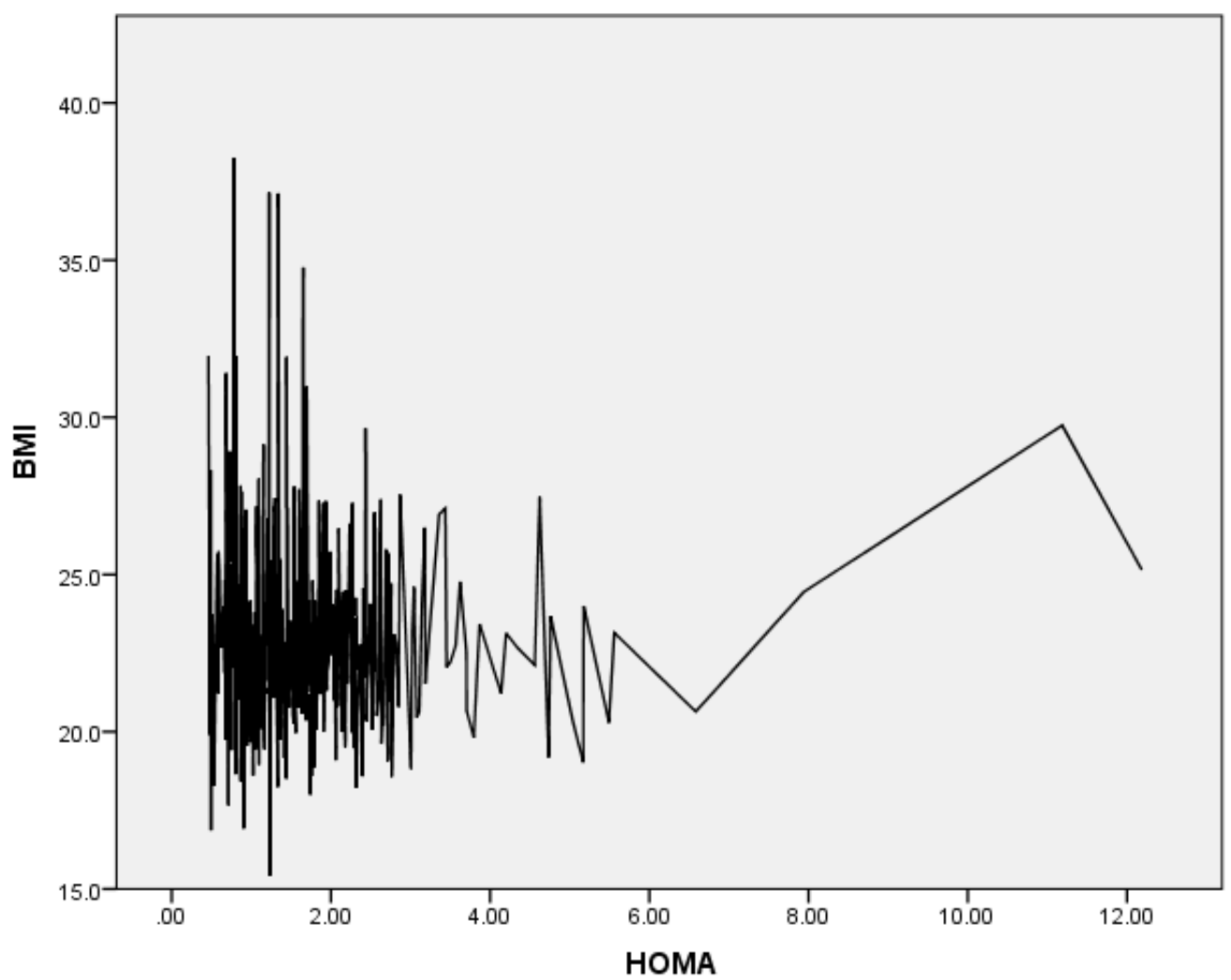

Graph 4: Insulin resistance versus BMI.

Table 5: Days a week that physical activity is performed according to BMI and PA.

\begin{tabular}{|c|c|c|c|c|c|c|c|c|c|}
\hline & & \multicolumn{4}{|c|}{ BMI* } & \multicolumn{4}{|c|}{ PA $>80$ Female $y>90$ Male $* *$} \\
\hline & & \multicolumn{2}{|l|}{$<25$} & \multicolumn{2}{|c|}{$>25$} & \multicolumn{2}{|c|}{ Abnormal } & \multicolumn{2}{|c|}{ Normal } \\
\hline & & "n" & $\%$ & "n" & $\%$ & "n" & $\%$ & "n" & $\%$ \\
\hline \multicolumn{2}{|l|}{ No exercise } & 347 & 74.95 & 116 & 25.05 & 221 & 47.73 & 242 & 52.27 \\
\hline \multirow{2}{*}{1 to 2 days } & $<30$ & 14 & 56 & 11 & 44 & 12 & 48 & 13 & 52 \\
\hline & $>30$ & 199 & 75.67 & 64 & 24.33 & 105 & 39.92 & 158 & 60.08 \\
\hline \multirow{2}{*}{3 or more } & $<30$ & 6 & 66.67 & 3 & 33.33 & 3 & 33.33 & 6 & 66.67 \\
\hline & $>30$ & 92 & 74.80 & 31 & 25.20 & 36 & 29.27 & 87 & 70.73 \\
\hline
\end{tabular}

Table 6: BP high or normal risk factors studied.

\begin{tabular}{|l|l|l|l|}
\hline & \multicolumn{2}{|c|}{ BP (mmhg) } \\
\hline & $>130 / 85$ & $<130 / 85$ & $p$ \\
\hline BMI & $25.09 \pm 4.15$ & $22.99 \pm 2.87$ & 0.0001 \\
\hline Triglycerides & $107.5 \pm 52.6$ & 96.146 .7 & 0.02 \\
\hline Cholesterol HDL & $49.2 \pm 12.5$ & $52.1 \pm 11.3$ & 0.001 \\
\hline Waist diameter & $87.1 \pm 9.6$ & $80.9 \pm 7.7$ & 0.0001 \\
\hline
\end{tabular}

Citation: Ruano Nieto CI, Melo Pérez JD, Mogrovejo Freire LE, De Paula Morales KR, Espinoza Romero CV (2015) Prevalence of Metabolic Syndrome and Associated Risk Factors in Medical Students of Universidad Central Del Ecuador. J Endocrinol Diab 2(3): 10. 


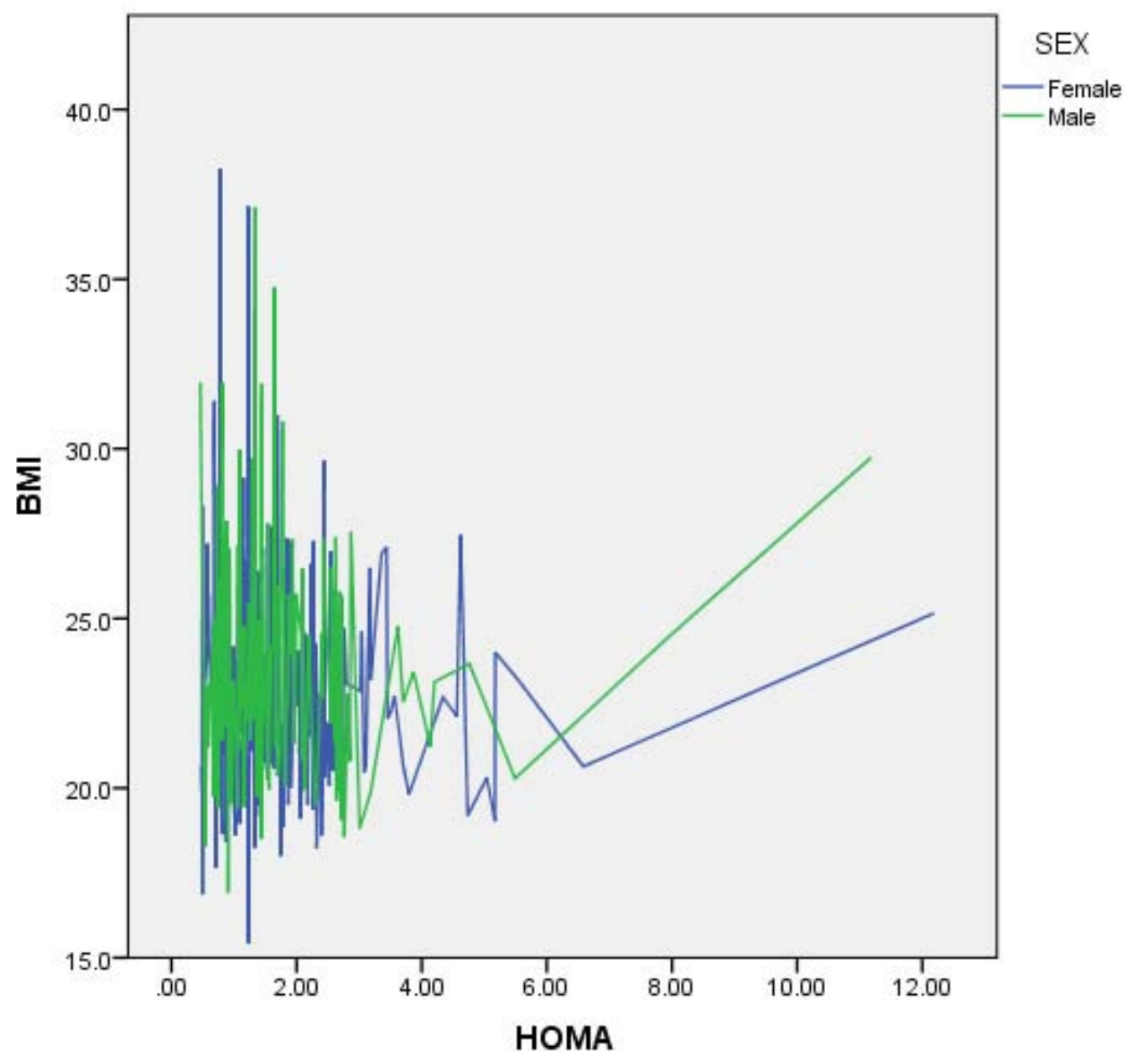

Graph 5: Insulin resistance versus BMI (stratified by sex).

$39.7 \%$, in contrast to $18.2 \%$ for men, data similar to those found in Mexican studies. [40,43] However, this data disagrees with that found in studies from countries such as Chile and Colombia, where low levels of HDL were significantly more common in men $[37,39]$ Triglyceride level was higher in men $(12.3 \%)$ than in woman (10.6\%), showing a higher level compared to the Chilean study [38].

BP levels were above the normal range more in men than in women $(24.4 \%$ vs $9.8 \%)$, same results as in the studies cited previously $[37,39]$ One thing that stands out is the probable association between the risk of developing hypertension at an early age and the presence of risk factors such as abnormal levels of triglycerides, BMI and WC.

Overall, it can be said that risk factors such as lipid profile, BP, blood glucose, BMI and WC are increase in students diagnosed with MS in relation to the healthy ones. In the same way, subjects with obesity and overweight showed values much higher than those reporting normal weight which is consistent with the literature [44].

hsCRP concentration is an independent risk factor and predictor of coronary heart disease. In adults, elevated hsCRP was significantly associated with body fat and specific components of MS [45] Adolescents and young adults' data in the field are limited. There have been some reports that levels of hsCRP and cardiovascular risk are similar to those of adults [46].

Few studies assessed the association between markers of inflammation and metabolic risk (insulin resistance, hypertension, dyslipidemia), this effect seems to be attenuated when obesity is adjusted. A study in Mexican children concludes that there is little evidence on the association between obesity, inflammation and cardiovascular risk factors [2]. They found that concentrations of IL- 6 correlate with BMI, but were not associated with insulin resistance when the model was adjusted for obesity and lipid concentration [2]. In a study conducted in Argentina among adolescent students, the hsCRP values were not different among adolescents with and without MS [44]. Other authors have reported higher levels of hsCRP in adolescents with MS. In this study hsCRP levels show a different behavior, it was found that the average hsCRP according to the WC is higher in normal subjects, this does not persist with the IL6, where the value is slightly higher in those with altered WC. For students who do not present any metabolic disorder, an increase value of hsCRP compared to those with MS was also found. The value of IL-6 is slightly higher in subjects with MS than in the healthy students. When correlated with BMI, the trend was observed again; those 
with normal weight reported a greater CRP value than overweight or obese. IL-6 was higher in the overweight and obese population, compared to the healthy ones with a statistically significant difference $(p<0.05)$. To rule out any kind of outside interference in the results of hsCRP, all subjects who reported some type of infectious disease (bacterial or viral) 15 days prior to sampling and subjects with leukocytosis were excluded (>10.000). Data were stratified according to lipid profiles to rule out that these values were responsible for the changes in CRP levels, and it was found no relationship. hsCRP data obtained in this study are not consistent with those reported by other authors, so that further studies are needed in young Ecuadorian population.If these data are repeated, it is necessary to rule out other variables such as age or genetics that are determining this type of behavior. The risk of cardiovascular events in our young people could be increased; however, it points out that the number of overweight students with altered WC and SM has lower concentrations of hsCRP than those found in normal individuals.

Regarding data from insulin resistance, there was no relationship between this parameter and BMI. This data is not consistent with the literature. The problem related with the HOMA-IR index can be attributed to the fact that insulin measure was made after, in a sample collected and saved in ultra freezing (-70 degrees Celsius) in a primary collector tube with gel separator. It is possible that the sample suffered contamination with red blood cells and this produced false low insulin levels.

\section{Conclusions}

Some studies have shown an association between the presence of MS in children and adolescents in the long term, especially due to the morbidity and mortality that these can cause. This morbidity and mortality have increased in younger ages and prospective studies are needed to clarify the true diagnostic value of MS in young people.

The prevalence of metabolic syndrome was $8.2 \%$ and only $34 \%$ of the population presented no risk factors for MS. 1 out of 4 students have some degree of overweight or obesity. A significant percentage of students presented alterations in plasma lipid levels and blood pressure. While most students are still in lowrisk categories, authors should continue doing this type of studies that will allow increasing awareness of the presence of risk for chronic non transmissible diseases and diagnosing and treating properly the MS patients.

Our results confirm the need to establish primary prevention programs of non-infectious diseases, it should be considered as a priority in health matters in populations like ours that are facing nutritional problems.

\section{Limitations}

A limitation of the study was the fact that insulin levels were measured in a saved sample, and for these reasons the obtained values have to be interpreted with caution.

A new study to measure the real values of insulin is now being developed by the authors. We believe this new study will clarify the data regarding insulin resistance.

NETLAB SA, clinical laboratory accredited under ISO 15189 international standards and certification Standardization LIPIDS PROGRAM CDC Atlanta.

\section{Acknowledgement}

Students of First, Second and Third semester in the AprilSeptember 2014 period, from the School of Medicine of the Universidad Central del Ecuador.

\section{References}

1. Cali AM, Caprio S. Obesity in children and adolescents. J Clin Endocrinol Metab. 2008;93(11 Suppl 1):S31-S36. doi: 10.1210/jc.2008-1363.

2. Perichart-Perera O, Balas-Nakash M, Schiffman-Selechnik E, BarbatoDosal A, Vadillo-Ortega F. Obesity increases metabolic syndrome risk factors in school-aged children from an urban school in Mexico city. J Am Diet Assoc. 2007;107(1):81-91.

3. Diet and lifestyle recommendations revision. a scientific statement from the American Heart Association Nutrition Committee. Circulation. 2006;114:82-96.

4. Cockrell A, Steiner MJ, Henderson FW, Perrin EM. Multiple markers of inflammation and weight status: cross-sectional analyses throughout childhood. Pediatrics. 2010;125(4):e801-e809. doi: 10.1542/ peds.2009-2182.

5. World Health Organization. Obesity: preventing and managing the global epidemic. Geneva: WHO; 2004.

6. Taylor AE, Ebrahim S, Ben-Shlomo Y, MartinRM, Whincup $\mathrm{PH}$, Yarnell JW, et al. Comparison of the Associations of Body Mass Index and Measures of Central Adiposity and Fat Mass with Coronary Heart Disease, Diabetes, and All-cause : a Study Using Data From 4 UK Cohorts. Am J Clin Nutr. 2010;91(3):547-556. doi: 10.3945/ ajcn.2009.28757.

7. Muros Molina JJ, Oliveras López MJ, Mayor Reyes M, Reyes Burgos T, López García de la Serrana H. Influence of physical activity and dietary habits on lipid profile, blood pressure and BMI in subjects with metabolic syndrome. Nutr Hosp. 2011;26(5):1105-1109. doi: 10.1590/S0212-16112011000500027.

8. Caro J, Navarro I, Romero P, Lorente RI, Priego MA, MartínezHervás S, et al. Metabolic effects of regular physical exercise in healthy population. Endocrinol Nutr. 2013;60(4):167-172. doi: 10.1016/j.endonu.2012.11.004.

9. Wozniak SE, Gee LL, Wachtel MS, Frezza EE. Adipose tissue: the new endocrine organ? A review article. Dig Dis Sci. 2009;54(9):1847-1856. doi: 10.1007/s10620-008-0585-3.

10. Calabro P, Limongelli G, Pacileo G, Di Salvo G, Golino P, Calabro R. The role of adiposity as a determinat of an inflammatory milieu. J Cardiovasc Med (Hagerstown). 2008;9(5):450-460. doi: 10.2459/ JCM.0b013e3282eee9a8.

11. Egger G, Dixon J. Should obesity be the main game? Or do we need an environmental makeover to combat the inflammatory and chronic disease epidemics? Obes Rev. 2009;10(2):237-249. doi: 10.1111/j.1467-789X.2008.00542.x.

12. Aguilar Cordero MJ, González Jiménez E, Perona JS, Alvarez Ferre J, Padilla López CA, Rivas García F. Ceruloplasmin and its clinical relevance as an indactor of cardiovascular risk factor in a school population of Granada. Nutr Hosp. 2011;26(3):655-658. doi: 10.1590/ 


\section{S0212-16112011000300033.}

13. Ritchie SA, Connell JM. The link between abdominal obesity, metabolic syndrome and cardiovascular disease. Nutr Metab Cardiovasc Dis. 2007;17(4):319-326

14. Mauras N, Delgiorno C, Kollman C, Bird K, Morgan M, Sweeten S, et al. Obesity without established comorbidities of the metabolic syndrome is associated with a proinflammatory and prothrombotic state, even before the onset of puberty in children. J Clin Endocrino Metab. 2010;95(3):1060-1068. doi: 10.1210/jc.2009-1887.

15. Galcheva SV, Iotova VM, Yotov YT, Bernasconi S, Street ME. Circulating proinflammatory peptides related to abdominal adiposity and cardiometabolic risk factors in healthy prepubertal children. Eur J Endocrinol. 2011;164(4):553-558. doi: 10.1530/EJE-10-1124.

16. Caballero AE, Bousquet-Santos K, Robles-Osorio L, Montagnani V, Soodini G, Porramatikul S, et al. Overweight Latino children and adolescents have marked endothelial dysfunction and subclinical vascular inflammation in association with excess body fat and insulin resistance. Diabetes Care. 2008;31(3):576-582.

17. Khaodhiar L, Ling PR, Blackburn GL, Bistrian BR. Serum levels of interleukin- 6 and C-reactive protein correlate with body mass index across the broad range of obesity. JPEN J Parenter Enteral Nutr. 2004;28(6):410-415.

18. Ridker PM. Clinical application of C-reactive protein for cardiovascular disease detection and prevention. Circulation. 2003;107(3):363-369.

19. Kones R. Primary prevention of coronary heart disease: integration of new data, evolving views, revised goals, and role of rosuvastatin in management. A comprehensive survey. Drug Des Devel Ther. 2011;5:325-380. doi: 10.2147/DDDT.S14934.

20. Acevedo M, Arnaiz P, Barja S, Bambs C, Berrios X, Guzman B, Carvajala et al. Protein $C$ reactiva y su relación con adiposidad, factores de riesgo cardiovasculary aterosclerosis subclinica en niños sanos. Rev Esp Cardiol. 2007;60(10):1051-1058

21. Bonetti PO, Lerman LO, Lerman A. Endothelial dysfunction: a marker of atherosclerotic risk. Arterioscler Thromb Vasc Biol. 2003;23(2):168175 .

22. Akinci G, Akinci B, Coskun S, Bayindir P, Hekimsoy Z, Ozmen B Evaluation of markers of inflammation, insulin resistance and endothelial dysfunction in children at risk for overweight. Hormones (Athens). 2008;7(2):156-162.

23. Taylor AE, Ebrahim S, Ben-Shlomo Y, Martin RM, Whincup PH, Yarnell JW, et al. Comparison of the associations of body mass index and measures of central adiposity and fat mass with coronary heart disease, diabetes, and all-cause mortality: a study using data from 4 UK cohorts. Am J Clin Nutr. 2010;91(3):547-556. doi: 10.3945/ ajcn.2009.28757.

24. López-Jaramillo P, Rueda-Clausen CF, Silva FA. The utility of different definitions of metabolic syndrome in Andean population. Int J Cardiol. 2007;116(3):421-422.

25. Encuesta Nacional de Salud y Nutrición ENSANUT. Ministerio de Salud Pública de la República del Ecuador. 2011-2013.

26.Yepez, R, Carrasco, F, Baldeón, M. Prevalence of overweight and obesity in adolescents Ecuadorian urban students. Arch Latinoam Nutr. 2008;58(2):139-143.

27. Ruano Nieto C, Melo Pérez J, Mogrovejo Freire L, De Paula Morales KR, Espinoza Romero C.V. Prevalence of metabolic syndrome and associated risk factors in ecuadorian universi- ty students. Nutr Hosp. 2015;31(4):1574-1581. doi: 10.3305/ nh.2015.31.4.8371.

28. Hussain A, Claussen B, Ramachandran A, Williams R. Prevention of type 2 diabetes: A review. Diabetes Res Clin Pract. 2007;76(3):317326.

29. Trichopoulou A, Costacou T, Bamia C, Trichopoulos D. Adherence to a mediterranean diet and survival in a Greek population. N Engl J Med. 2003;348(26):2599-2608.

30. The Diabetes and Nutrition study group of the Spanish Diabetes Association (GSEDNu). Diabetes Nutrition and Complications Trial: adherence to the ADA nutritional recommendations, targets of metabolic control, and onset of diabetes complications. A 7-year, prospective, population-based, observational multicenter study. J Diabetes Complications. 2006;20(6):361-366.

31. Montero Bravo A, Martín Ubeda N, García Gonzalez A. Evaluation of dietary habits of a population of university students in relation with their nutritional knowledge. Nutr Hosp. 2006;21(4):466-473.

32. Oliveras López MJ, Nieto Guindo P, Agudo Aponte E, Martínez Martínez F, López García de la Serrana H, López Martinéz MC. Nutritional assessment of a university population. Nutr Hosp. 2006;21(2):179183.

33. Alberti KG, Eckel RH, Grundy SM, Zimmet PZ, Cleeman JI, Donato KA, et al. Harmonizing the metabolic syndrome: a joint interim statement of the International Diabetes Federation Task Force on Epidemiology and Prevention; National Heart, Lung, and Blood Institute; American Heart Association; World Heart Federation; International Atherosclerosis Society; and International Association for the Study of Obesity. Circulation. 2009;120(16):1640-1645. doi: 10.1161/ CIRCULATIONAHA.109.192644.

34. Matthews DR, Hosker JP, Rudenski AS, Naylor BA, Treacher DF, Turner RC. Homeostasis model assessment: insulin resistance and beta-cell function from fasting plasma glucose and insulin concentrations in man. Diabetologia. 1985;28(7):412-419.

35. Huang TT, Johnson MS, Goran MI. Development of a prediction equation for insulin sensitivity from anthropometry and fasting insulin in prepubertal and early pubertal children. Diabetes Care. 2002;25(7):1203-1210.

36. Vasques AC, Rosado LE, Cássia G. Alfenas R, Geloneze B. Critical analysis on the use of the homeostasis model assessment (HOMA) indexes in the evaluation of the insulin resistance and the pancreatic beta cells functional capacity. Arq Bras Endocrinol Metabol. 2008;52(1):32-39.

37. Feliciano-Alfonso JE, Mendivil CO, Ariza ID, Pérez CE. Cardiovascular risk factors and metabolic syndrome in a population of young students from the national university of Colombia. Rev Assoc Med Bras. 2010;56(3):293-298

38.G. Oviedo y cols. Factores de riesgo de enfermedades crónicas no transmisibles en estudiantes de la carrera de Medicina. Universidad de Carabobo, Venezuela. Año 2006. Nutrición Hospitalaria 2008; 23:288-293.

39. Palomo IF, Gaby IT, Marcelo AA, Patricio JM, Elba L, Verónic M. Alta prevalencia de factores de riesgo cardiovascular clásicos en una población de estudiantes universitarios de la región centro-sur de Chile. Rev Esp Cardiol. 2006;59(11):1099-105.

40. Arturo MJV, Cuitláhuac CAC, Maria de JOG, Carlos GA, Cortes, Nalda LG. Prevalencia de factores de riesgo cardiometabólico en estudiantes universitarios de la región centro-occidente, en la Universidad Michoacana de San Nicolás de Hidalgo, México. Rev Mex Cardiol. 


$$
\text { 2013;24(2):76-86. }
$$

41. Bojorges Velázquez LA, Castillo Herrera JA, Jiménez Tamayo R. Factores de riesgo de síndrome metabólico en estudiantes de la universidad Pablo Guardado Chávez, año 2013. REF PUB: Revista Cubana de Investigaciones Biomédicas. 32(4-2013):379-388.

42. Trujillo-Hernández Benjamín, Clemente Vásquez, José R. AlmanzaSilva, María E. Jaramillo-Virgen, Tadeana E. Mellin-Landa, Ofelia B. Valle-Figueroa, Roberto Pérez-Ayala. Frecuencia y factores de riesgo asociados a sobrepeso y obesidad en universitarios de Colima, México. Rev. Salud pública. 2010;12(2):197-207.

43. González Sandoval Claudia Elena y cols. Prevalencia de obesidad y perfil lipídico alterado en jóvenes universitarios. Nutrición Hospitalaria. 2014;29:315-321.
44. Graffigna MN, Honfi M, Soutelo J, Migliano M, Ledesma L, Proietti A, et al.. Síndrome metabólico y riesgo cardiovascular en estudiantes adolescentes de la ciudad de Buenos Aires. Rev Arg Endocrinol Metabol. 2010;47(2):14-20.

45. Ridker PM, Buring JE, Cook NR, Rifai N. C-reactive protein, the metabolic syndrome, and risk of incident cardiovascular events: an 8-year follow-up of 14719 initially healthy American women. Circulation. 2003;107(3):391-397.

46. Kelishadi R, Sharifi M, Khosravi A, Adeli K. Relationship between $\mathrm{C}$-reactive protein and atherosclerotic risk factors and oxidative stress markers among young persons 10-18 years old. Clin Chem. 2007;53(3):456-464. 